\title{
Working-Time Flexibility and Full- Time Work in a Retail Banking Organisation
}

\section{Jenny Whittard and John Burgess}

ABSTRACT: In this article we seek to examine how full-time workers can attain working-time flexibility through formal and informal mechanisms. To explore averues for flexibitity for full-iine employees who have caring responsibilities, we look at a single case-study of a retail-banking organisation with a non-union enterprise agreement that pays particular attention to the codification of workingtime issues. Through interviews with the human resoturces department, line managers and full-time employees, the case study dertonstrates how within one organisational context, the length of the 'normal' working week has expanded, with weekend work and unpaid owertime merged in to the organisational assimption of ordinary hours. The case study highlights the impact of this expansion on full-time employees with caring commitments and the intersection of caring commitments and working-time flexibilities. Much of the working-time flexibility available to full-time employees was informal in nature, dependent on workplace circumstances, and its implementation was entirely up to the discretion of line managers. The research illustrates how line managers could choose to facilitate employee-based flexibility in working hours but typically this required them to either intensify work for the remaining workforce or intensify work for the managers themselves.

\section{Introduction}

One of the major developments in the Australian workforce has been the maintenance of participation or the return to work of women after child bearing. Growing participation rates of women have taken place across all age groups, including traditional child-bearing and child-caring ages of twenty to 44 years of age. While much of the increase in female labour-force participation has been 
charnelled into part-time work, there is growth in female full-time employment and in the female share of full-time employment (Campbell and Charlesworth 2004). This has meant that there are now more households with children and dual labour force participation, and that more women are combining care and paid work. While part-time and casual work is the major way that Australian women accommodate work and care (Pocock 2003), a growing number of women are combining full-time work and caring duties.

Flexibility brings benefits and concerns from both an employer and an employee perspective and remains a contentious issue (Sheridan and Conway 2001). In this article we seek to examine how full-time workers with caring responsibilities can use formal and informal means to attain enough working-time flexibility to balance their work and family responsibilities. Through interviews with Human Resources (HR), line managers and full-time employees, the case study illustrates how firstly, in this organisation, the length of the 'normal' working week had expanded, with after-hours and weekend work merged into the ordinary hours of employment and the operational assumptions of unpaid overtime. The implications of this are explored through the experiences of full-time employees - in particular the time pressures experienced and the intersection of caring commitments and working-time tlexibility for full-time workers (Bittman and Rice 2002). An examination of working-time flexibility available for full-time employees is then undertaken. As Whittard (2004) found, these systems operate informally and are entirely up to the discretion of line managers. Line managers in their workplaces can choose to facilitate employee-based flexibility in working hours but typically this required them to either intensify work for the remaining workforce or intensify work for the managers themselves. 1

The case illustrates how institutional and managerial impediments to implementing flexible working-time arrangements for employees with family commitments can limit access to these types of flexibility. In the absence of formal policy support in this area, negotiating informal mechanisms at the workplace level to access working-time flexibility becomes important (Whittard 2004).

\section{Conceptualising Working-Time Flexibility with Work and Family Balance}

Flexibility is a critical working-time issue associated with work-family balance (Thornthwaite 2004). Felstead et al. (2002: 54) define flexible working-time practices in relation to work and family as those which provide 'some degree of responsiveness and adaptability' to help employees reconcile work and family needs. What are the different types of flexibility required by employees? Berg et al. 
(2004: 331-32) distinguish between employer and employee control over working time and define the latter as the ability of individual workers to increase or decrease their working hours and to alter their work schedules'. Eaton (2003: 146) defines flexibility more broadly to include flextime, or 'the ability to schedule flexible starting and quitting times, sometimes with a core-hours requirement', but also encompassing the ability to work part-time at certain points in life, to take days off in return for working non-standard times, and to take time off for utgent (such as family illness) or non-urgent (such as visits to schools and appointments) care issues. Berg et al. (2004) in their examination of employee control over working time in seven countries highlight the variation in tlexible forms of working time. These include schemes such as flextime, job sharing, telecommuting, part-time work, compressed workweeks, variable weekly working times, and averaging work time across short periods or even up to a year. Traditional avemues for workingtime flexibility for full-time workers include access to paid holidays and other forms of leave, rostered days off, flextime work arrangenents, and a defined and predictable spread of working hours.

Flexible working-time practices can be considered within a framework of work and care reconciliation. Hein (2005), for example, suggests that work and care reconciliation can be classified into three main areas of need: establishing routines so that work and care responsibilities can be planned and fulfilled; coping with major family events such as childbirth and illness; and coping with short-tem emergencies.

Superimposed over these needs are five main measures that potentially address these needs: leave entitlements; work schedules; workplace flexibility; care facilities; and reducing the burden of family tasks.

Table 1 shows how these needs and measures are integrated. It is important to distinguish between statutory rights that are available to all workers and conditions that are negotiated and available to a few workers. Hence, the authority for access to and implementation of arrangements is important. An extensive regime of supporting programs and policies to reconcile work and care may be present, but it may apply to a minority of the workforce or have qualifying conditions that limit its application. In Australia the most important limiting condition is that of casual employment, which is predominantly located in part-time work. In this case study, however, we consider the position of full-time workers. While full-time workers have permanent status and leave entitlements, accessing those entitlements in a way that reconciles work and family responsibilities is another matter (Morehead 2003). 


\section{Table 1: Reconciling work and family}

\begin{tabular}{|c|c|c|c|}
\hline Measure & Workable Routines & $\begin{array}{l}\text { Coping with Major } \\
\text { Events }\end{array}$ & $\begin{array}{l}\text { Coping with } \\
\text { Emergencies }\end{array}$ \\
\hline Leave arrangements & $\begin{array}{l}\text { - Annual leave } \\
\text { - Choice cuer leave }\end{array}$ & $\begin{array}{l}\text { - Maternity and } \\
\text { paternity leave } \\
\text { - Parental leave } \\
\text { - Reintegration atter } \\
\text { absence }\end{array}$ & $\begin{array}{l}\text { - Annual leave } \\
\text { - Sick leave } \\
\text { - Emergency leave } \\
\text { - Parental leave }\end{array}$ \\
\hline Work schedules & $\begin{array}{l}\text { - Avoiding long hours } \\
\text { - Regular work } \\
\text { schedules } \\
\text { - Part-bime hours } \\
\text { - Flexi-time } \\
\text { - Working during } \\
\text { school time }\end{array}$ & $\begin{array}{l}\text { Ability to temporarily } \\
\text { reduce hours }\end{array}$ & - Flextime \\
\hline Place of work & $\begin{array}{l}\text { - Working from hame } \\
\text { - Telework }\end{array}$ & $\begin{array}{l}\text { - Working from home } \\
\text { - Telework }\end{array}$ & $\begin{array}{l}\text { - Working from home } \\
\text { - Telework. }\end{array}$ \\
\hline Care facilities & $\begin{array}{l}\text { - Access to affordable } \\
\text { care for children and } \\
\text { elderly } \\
\text { - Out of school hours } \\
\text { supervision }\end{array}$ & $\begin{array}{l}\text { - Breastfeeding } \\
\text { facilities }\end{array}$ & $\begin{array}{l}\text { - Emergency care } \\
\text { arrangements } \\
\text { - Ability to bring } \\
\text { children to work }\end{array}$ \\
\hline $\begin{array}{l}\text { Reduced burden of } \\
\text { family tasks }\end{array}$ & $\begin{array}{l}\text { - Coincidence between } \\
\text { work and school hours } \\
\text { - Retail and tracing } \\
\text { hours } \\
\text { - Transport facilities }\end{array}$ & & \\
\hline
\end{tabular}

Source: From Hein (2005: 34)

This study demonstrates features of the Australian work-and-family care regime that have been highlighted previously (see Pocock 2003). Measures that support planned and unplanned conflicts between work and care are generally absent, while reconciliation is left to the individual and relies on mechanisms both outside and inside the workplace. In particular, major events and emergencies place enormous pressure on individuals, families and workplaces where there is an absence of formal mechanisms and processes of accommodation (Charlesworth et al. 2002). In this context discretion and support falls to line managers, a process that results in the workplace offering uneven and arbitrary accommodation of work-and-family care (Eaton 2003).

\section{Managing Work and Family Reconciliation within the Workplace}

Predictable and unpredictable pressures arising from family responsibilities (Campbell and Charlesworth 2004) create the demands for employee control over 
working time. Indeed unpredictable sicknesses or accidents, for example, have been described by Pocock (2003: 192) as 'every worker/carer's nightmare', moments when caring and.paid employment are arguably at their greatest tension. Thornthwaite's (2004) review of research on working-time flexibility in Australia suggests job flexibility is positioned for many working parents as more critical for creating time with children than reduced working hours. This is the case particularly for women (Thornthwaite 2004: 176), as a reflection of both the domestic division of labour within households and also difficulties in the practice of accommodating work to school hours and calendars within the limits of available, accessible, affordable childcare - in particular for infants, for emergencies and vacations, and other situations of irregular demand and non-standard working hours (Bittman and Rice 2002; Thornthwaite 2002; Thornthwaite 2004).

One of the factors emerging from the literature is the discretion of line managers in work and family reconciliation. The role of line managers in the employment relationship has attracted considerable research attention (Currie and Proctor 2001; Renwick and MacNeil 2002). The current work-and-family debate highlights the significant role of managers from all organisational levels in the reconciliation of work and family (Bardoel 2003; Campbell and Charlesworth 2003; Pocock 2003).

Workplace arrangements play a key role in facilitating or frustrating efforts to manage the tensions between work and caring roles, and efforts made by employers and supervisors to make work more care-friendly are valued by employees (Pocock 2003: 248). In her research involving a Canberra hospital, Morehead (2003: 92) used the term 'room to move' to describe the discretion available to both supervisors and employees in the setting and management of working-time arrangements. In particular, mothers developed strategies to maintain their presence in the workplace and managed their absence from the home.

Concerns about line manager involvement in human resource management (HRM) functions have also been identified in the relevant literature. For example, giving employees control over working time and hence flexibility to manage their commitments requires managers to relinquish their control and relies on their ability to reorganise workload or substitute employees. Wise and Bond (2003: 26) suggest that policy based on cost cutting, like closely matching labour supply to demand in a time-crucial customer-service task, is unlikely to enable managers to meet employee needs for control and flexibility. Other concerns have also been, raised in the HRM literature regarding 'potential areas of abuse of line management power and authority' through work intensification or offloading duties to junior staff members to meet operational requirements (Renwick and MacNeil 2002: 408). Studies have highlighted resistance by supervisors and managers as a major barrier to the use and effectiveness of flexible work arrangements (Schwartz 1994: 34). As 
Lewis and Taylor (1996) found from their case study of UK chartered accountants, some managers also feared that schemes such as reduced hours may be open to abuse or that co-workers would see such schemes as perks and therefore perceptions of unfairness within the workplace environment would form. Management discretion over initiatives like reducing working time was 'not something that will be readily relinquished as it is seen as a necessary safeguard against the threat of loss of power and autonomy for managers to run their departments' (Lewis and Taylor 1996: 119). As Schwartz (1994: 34) concluded in her review:

... supervisors are the key mediators affecting a range of outcomes in the workplace - employee satisfaction and loyalty, level of work-family conflict, perceived trade offs between work and personal life, and the impact of family-friendly policies.

The literature has also highlighted that managerial support can become part of reward mechanisms to enhance managerial control. Fletcher and Rapoport (1996: 148), found that managers who have tight control of approvals for access to work-family policies may approve access on the basis of the past performance of 'deserving' employees. Wise and Bond (2003) and Dex and Scheibl (2001) also encountered the notion of a 'give and take' relationship regarding access to policy. Eaton (2003) suggests that availability and usage of formal policies may be either encouraged or discouraged by supervisors, but that supervisors can also permit more flexibility than policy allows. Line managers can operate outside policy and permit 'informal flexibility' by 'encouraging employees to take time off unofficially, so that flexibility becomes invisible to higher level managers' (Eaton 2003: 147).

In summary, the issues of working-time flexibility and reconciliation of work and family within the workplace are intertwined. While the literature emphasises the im portant role of working-time flexibility in managing care commitments and that formal mechanisms can exist to facilitate employee control in this area, the extent to which individuals gain control over working time occurs in an operational context moderated by the employer and in particular the line manager.

\section{The Case Study and the Case Study Organisation}

Case studies can provide insights into the complex processes at play within an organisation and the interactions with the wider environment (Kitay and Callus 1998: 104). However, they have limitations and therefore cannot be generalised to the broader industry experience (Kitay and Callus 1998). Information for this case study was collected from multiple sources. Analysis of company documents, observation and interviews with employees and managers were the primary data 
generation methods but this was supplemented by examining existing in-house survey data. A qualitative research method was adopted, given the research focus on organisational practice.

FinanceCo, the case-study organisation, is a medium-sized (approximately 500 employees) financial institution located in New South Wales, providing a range of business and personal financial products and services. In its provision of services, it is similar to retail banking organisations. It operates within a competitive local market for financial services and products and there is an emphasis on staff service as a means of product differentiation. The organisation is struchured into a customer service branch network of approximately 40 service points supported by five head office administrative and support areas. The network of service points are spatially distributed throughout regional locations and concentrated in suburban clusters.

The interview component of the research was undertaken between August 2002 and January 2003. In a face-to-face interview, participants were asked to share their experiences and perspectives in relation to a number of different topics. A set of pre-determined standard topics were supplemented with openended questions, and modified depending on the particular circumstances of the interview or characteristics of the interview participant. This combination of structured and unstructured questioning allowed for comparability of responses but also provided the flexibility to respond to the different circumstances of each interview and allowed more specific and detailed understanding of individual situations. Some participants aiso responded to two separate sets of interview questions based on their general experiences as employees or their specific experiences in different roles within the organisation (for example, as a manager of a workplace). Demographic information such as gender, employment status, and dependant care responsibilities (presence of children under eighteen years of age) was also collected.

In total, 92 interviews were conducted within Finance $C o$. The profile of these participants is listed in Table 2 . These included discussions with key informants in human resources and interviews with employees across sixteen head office and branch worksites. The interview data were grouped and compared based on common themes and key worch. This article discusses the general analysis of findings from all interviews and in particular focuses on information from two subsets of interview data: twenty interviews with full-time employees with dependant care responsibilities and 31 interviews with line managers. Of all the participants interviewed, nearly half (45) were parents with dependant care responsibilities. While the majority of these (25) were working 'part-time' (all of these participants were female), twenty parents (thirteen of these female) 


\section{Table 2: FinanceCo interview participant profile}

\begin{tabular}{|c|c|c|}
\hline & Number of participants & $\%$ of participants \\
\hline \multicolumn{3}{|l|}{ Employment status } \\
\hline Full-time hours & 67 & 73 \\
\hline Less than full-time ( 38 hours per week) & 25 & 27 \\
\hline - Part-lime & 16 & \\
\hline - Casual & 4 & \\
\hline - Job share & 5 & \\
\hline \multicolumn{3}{|l|}{ Gender } \\
\hline Male & 13 & 14 \\
\hline Female & 79 & 86 \\
\hline \multicolumn{3}{|l|}{ Workplace } \\
\hline Head Office & 13 & $\uparrow 4$ \\
\hline Branch Network & 79 & 86 \\
\hline \multicolumn{3}{|l|}{ Dependants } \\
\hline Dependants (18 years or under) & 45 & 49 \\
\hline No dependants & 47 & 51 \\
\hline \multicolumn{3}{|l|}{ Tenure } \\
\hline $0-2$ yrs & 25 & 27 \\
\hline $3-5 \mathrm{yrs}$ & 14 & 15 \\
\hline $6-10$ yrs & 21 & 23 \\
\hline $11+y r s$ & 32 & 35 \\
\hline \multicolumn{3}{|l|}{ Occupation } \\
\hline Branch Staff & 53 & 58 \\
\hline Clerical Staff & 8 & 9 \\
\hline Supervisor & 9 & 10 \\
\hline Managing Supervisor / Assistant Manager & 8 & 9 \\
\hline Department/ Branch Manager & 14 & 15 \\
\hline Total Participants & 92 & 100 \\
\hline
\end{tabular}

Source: FinanceCo interview data

worked on a full-time basis. The topics these employees were asked to discuss included their experiences and strategies for managing work and care demands and their perspective on the policies and practices in operation in FinanceCo. Line managers were also asked to discuss topics such as their experiences of organisational policy and their specific experience of managing employees with work-and-family commitments. In this organisational context, line managers or 
front-line managers consisted of supervisors, managing supervisors/assistant managers, and managers in branches and head office departments (see Table 2). Within each of the sixteen workplaces examined at least one line manager was interviewed.

As Table 3 illustrates, the majority of employees in the organisation work fulltime ( 38 hours spread across a 5.5 day working week). Within this organisational context, 'part-time' work encompasses several employment arrangements including permanent part-time work, on-call casual work, and job sharing. Approximately half of the employees are located within the organisation's branch network where different types of flexible utilisation of labour are required. Table 3 also provides a breakdown of the head-office and branch employment and indicates that it is in the branch network that permanent part-time, job sharing, and casual employment are concentrated. About 70 per cent of branch employees work full-time, while the equivalent figure in the head office is 90 per cent. From the employer's perspective, part-time employment meets a number of organisational requirements, including managing employee absence and the matching of workload peaks to labour supply.

\section{Table 3: Employment Status of Head Office/ Branch Staff Profile July 2002}

\begin{tabular}{lrrrrrr}
\hline & \multicolumn{2}{l}{ Head Office staff } & \multicolumn{2}{c}{ Branch staff } & \multicolumn{2}{c}{ Total } \\
\hline $\begin{array}{l}\text { Employment } \\
\text { Status }\end{array}$ & No. & $\%$ & No. & $\%$ & No. & $\%$ \\
Full-time & 148 & 90 & 228 & 69 & 376 & 76 \\
JS/PPT & 13 & 8 & 61 & 18 & 74 & 15 \\
Casual & 3 & 2 & 42 & 13 & 45 & 9 \\
\hline Totals & $\mathbf{1 6 4}$ & 100 & $\mathbf{3 3 1}$ & $\mathbf{1 0 0}$ & $\mathbf{4 9 5}$ & $\mathbf{1 0 0}$ \\
\hline
\end{tabular}

Source: FinanceCo workforce data

* (JS= Job Share; PPT= Permanent Part Time)

FinanceCo is dominated by women workers who provide services across a regional retail network and who make up 78 per cent of workforce (see Table 4). While the organisation does not collect data on the dependant care responsibilities of its employees, HR is aware that the demographic profile of employees in the organisation means the interaction of work and family is an ongoing issue for the organisation:

The majority of our staff are ladies in the age group ... they are probably twenty to 30 years when they start with us and obviously that's the age group 
when people get married, move on and have families, and we have a very large number of our staff do that. So we have to be very conscious of how we can fit in work and family movements.

\section{Table 4: Employment Status and Gender Profile March 2002}

\begin{tabular}{lrrrr}
\hline $\begin{array}{l}\text { Employment } \\
\text { Status }\end{array}$ & $\begin{array}{r}\text { Number of } \\
\text { Women }\end{array}$ & Number of Men & $\begin{array}{r}\text { Tolal } \\
\text { Employees }\end{array}$ & \% women \\
\hline Permanent full-time & 272 & 108 & 380 & 72 \\
Permanent part-time & 59 & 1 & 60 & 98 \\
Casual & 50 & 0 & 50 & 100 \\
\hline Totals & $\mathbf{3 8 1}$ & 109 & $\mathbf{4 9 0}$ & 78 \\
\hline
\end{tabular}

Soutce: Compiled from FinanceCo EoWA Workplace Program report March 2002

Arguably the main emphasis of organisational support by Financeco for employees with work-and-family commitments was on utilising numerical labour flexibility via casual, permanent part-time, and job-share employment artangements. The flexibility requirements of employees with care commitments were met by 'part-time' work. The majority of part-time employees were women and the HR department suggested women used these forms of employment;

mainly for family reasons because they have their kids and they don't want to work full tine ... they don't want to come back full-time yet, as I said not many people want to come back full-time.

\section{Working-Time Flexibility: Illustrative Findings}

Formal and operational aspects of full-time work in FinanceCo were raised as a concern for employees with dependant care responsibilities. In particular, interviews with full-time employees with dependants highlighted the tensions between work and care created by the length, spread and nature of operational requirements of the working week and the time pressures experienced by these employees. While there were some examples of working-time flexibility available in different workplaces within the organisation, these systems operated informally, were up to the discretion of line managers, and were subservient to operational requirements.

This industry has an uneven distribution of demand for its services across the day, the week and the year. FinanceCo maximised its flexibility in labour usage from full-time workers through a broad span of ordinary hours and limitations 
(formal and informal) on overtime claims. FinanceCo had a largely non-unionised workforce and employment conditions were regulated by an enterprise agreement (EA) negotiated directly with staff every three years. The regulation of working time was through a mix of formal company policy underpinned by the EA and informal practices. A comparison of selected conditions of employment in the EA operating during the interview period with the relevant award revealed that FinanceCo generally provided employees with above-award base-pay rates and extra leave provisions of twelve days recreation leave (with Rostered Days Off or RDOs). However, there was a wider span of normal ordinary working hours than was contained in the award. As the former HR manager described it:

Saturday work was always a tact of life [here] ... When we did our very first EA we also expanded the hours of work to include Sundays. Everyone was absolutely devastated, but as far as I know no-one has ever had to work on a Sunday. We decided back then that it looked like [the competition] were going to start going seven days a week and we thought we had better be prepared for it.

In practice, the organisation's current hours of operation in most of the branch customer service points was Monday 9 am to $5 \mathrm{pm}$ and Saturday 9 am to $12 \mathrm{pm}$, with some branches operating on Thursday evenings. In general, while some larger branches were able to structure their staffing in such a way that employees were only required to work every second Saturday, the experience in most branches was that full-time employees were required to work every Saturday. FinanceCo had also removed penalty rate provisions for Saturday and Thursday evening work by including these in the span of ordinary hours.

Generally, HR said, 'the biggest gripe of our staff is working every Saturday'. What was the impact of these working-time arrangements on full-time employees with care commitments? The length and spread of full-time working hours across the working week was described as a concern by employees generally within FinanceCo and specifically by those with family commitments. As one full-time manager explained:

We work long hours when you think of the days, when you include Saturdays, albeit, yes three hours, but you still have to get up, still got to get your family organised, so three hours is really six hours out of your day. I find that really sad, that we work on the weekend. I think five days is enough for everyone.

The effects of Saturday work on family life was identified as a particular concern because of its impact on time with family, on time for domestic activities, and on the practical ability to meet care commitments. One part-time employee 
explained, 'Saturday mornings with children and sport are things I have to miss'. One manager went on to describe not only the clash of Saturday work with family members' activities but also the difficulty of having to bring the children into the workplace:

I have had to bring the two younger ones with me to work and give them jobs to do down at the shop. Lucky they are old enough to be let loose out there and report back at different times, bring a book to the lunch room. Dragging them out of bed, they are not real happy about. I also choose to work back. If I have got them I can't. I try not to have them and stay back and work but then when I get home you can imagine, the house is a mess and people say, 'I wonder where dinner is'.

Another full-time manager described the tensions the full-time working week created:

I alternate every Saturday, so I am rostered off. But once you get home from work on a Saturday afternoon and have your lunch, there are not many hours in the day to do all your bits and pieces ... work around the house, doing the yard and washing and ironing.

Associated with these concerns about the working week for full-time employees were concerns about the extension of work time into unpaid personal time due to the span of full-time hours across the working day. The EA specified that employees in the branches work seven hours a day with a one hour unpaid lunch break and discretionary breaks. However, HR acknowledged that in the branches these paid hours did not reflect the actual working hours required. The EA contained assumptions of employer-focused flexibility in working time and unpaid overtime. With varying degrees of regularity, employees could be required to work beyond their standard daily hours. There was also a requirement to work extended hours, both with notice (for example, to attend out-of-hours meetings) and with little to no notice (for example if there were problems with balancing cash at the end of the day). This unpaid flexibility in working hours and extension of the workday was raised as a particular concern by managers. As one branch manager expressed, 'The [branch] hours that we work are from 9 am to $5 \mathrm{pm}$, the public sees that, we get paid from 9 to 5 . But the staff turn up at 8.40 am and they are back until $5.20 \mathrm{pm}$ nearly every day and it is not paid'. Another employee agreed:

It is $8.30 \mathrm{am}$ to $5.30 \mathrm{pm}$ most days. You don't close the doors until $5 \mathrm{pm}$, you have people here serving until 5.10 pm because of the public and then you have people having to balance, banking to balance. It becomes a long process before you can put the alarm on and go home. 
In the EA, in contrast to the award, overtime was formally only recognised where the employee was deemed to have worked more than fifteen minutes overtime on any one day. In practice, the requirements for accessing paid overtime were quite restrictive, and it was suggested that unpaid overtime was quite common. As this supervisor stated, 'You could never put in an overtime form because you had to stay back if someone was out [balancing cash]. They just wouldn't accept it'.

In particular, for managers with care commitments these extensions to unpaid working hours created problems:

It does get difficult to juggle things, the time involved, especially when there is a huge workload. Quite often I just have to ... Quite often I will be back here until fairly late in the day, which does tend to put a strain on things. If you look at it, I could be here until $6 \mathrm{pm}$ at night and my husband may be in the same position... If he has not got home to relieve my mother from the care of the children, it then means she has got a really long day too, so the pressure is on. That does not happen all the time ... and to this date she puts up with it, thankfully. I appreciate the help that I have got. (Female full-time manager)

HR suggested that the lack of penaity rates for Saturday work was offset by the provision of the twelve RDOs per year, while time-in-lieu was on offer to compensate for the reduced access to overtime. The unpaid extension of working hours within FinanceCo prompted line managers to expand the time-inlieu provision on a workplace basis and create other informal systems to allow employees to take time off for family commitments.

General statements about the pressures of full-time work-and-family commitments were expressed by both male and female participants. Statements such as these from a male full-timer illustrated the problem of having enough time in the day to spend time with children:

It's a bit hectic for me, getting up, getting them up in the morning, and getting them dressed before you go to work. Basically by the time you get home 5.30 to $6 \mathrm{pm}$, get them bathed, get them fed and into bed, that's about it ... you have to work to support the family so it is a bit of a catch. It is hard sometimes to come home and only spend like an hour with the kids before bed.

Participants spoke of 'missing some things' (female full-timer) in relation to time with children. As one participant explained: 'When they are at school you miss out on a few things. It is just something you have to accept if you work fulltime' (female employee).

Female full-time participants expressed concerns about their ability to cope with work and care commitments. When asked how she managed the care of her 
dependants, one female laughingly replied, 'I don't some weeks'. The lack of time the employees had for themselves was also emphasised, by a full-time manager who explained, 'Probably that's the thing I struggle with at times, if you could just have one day by yourself at home and you could have that catch up day, you cope'. As anothes: female manager noted:

As I say, I am coping with what I am coping with at the moment ... especially when you have got children at the age that mine are at. I have got one who is really still a baby, hasn't started school yet. She really depends on a lot of my time and then I have got a little boy who is eight, his school is getting a little bit more involved, he is wanting 'mum' to help him with things at school and all of that so it really becomes quite time consuming to fit the rest of it in.

Managing the interaction of paid working hours when both parents were in full-time paid employment was another of the concerns expressed. For this female manager the pressure of workload and family were particularly hard:

I have three children so that is a pretty tight situation and my husband works away a fair bit ... We are both full-time and the sad thing is ... we have a very hectic time.

One of the mechanisms parents used was organising employment hours between parental partners in order to maximise the availability for their children. Structuring working hours into shifts, while a beneficial strategy to minimise parental absence from the home, also required some personal intensification of work:

With my husband changing shifts ... I could only get [to work] at 9.30 so I had to rearrange things ... Start later to manage the drop [the children to school], cut my lunch breaks and on a Friday work later. (Female employee)

The tag team of two working parents, while maximising parental contact time with children, was at the expense of personal time parents spent together. One female full-timer also described family life and the effect of her partners' full-time shift work and her full-time hours:

[S]hift work can be difficult in itself ... it is good that [my husband] gets to play a role in dropping the kids [to school], which I don't really get to do. But it could also mean for that week, if he is on afternoon shift, we don't see each other for the week, so ... [laughed ruefully] ... it can get difficult. We normally have to have phone calls and remember who is picking kids up and doing what. It is difficult. 
Furthermore, general stress from full-time work was also seen to affect interaction with family members. One participant described her personal frustration:

I get home at 6.15 in the afternoon, I am pretty irritable and tired and I have to then cook dinner and they just sit down on their backsides as most teenage children do!! I say 'I have been working all day, why can't you help?' They just look at me and think, 'You cranky old witch!'. I get pretty irritable at the end of some days. It is tiring, really, really tiring. (Female full-timer)

The interviews in this research revealed a range of strategies and mechanisms used by employees to manage work and family life, each seemingly unique to the individual's circumstances. However, a number of themes emerged that were relevant to working-time requirements.

One of these themes was care, with such constraints shaping the preference for different types of work arrangements undertaken within the organisation. If full-time care was not possible, then some combination of part-time care and parttime work was preferred. Care responsibilities (as identified by Lee 2001) can be divided into regular or predictable care and occasional or unpredictable care, and each requires the creation of appropriate structures. For regular and predictable care, the strategies used by employees involved a complex mix of formal and informal solutions. Arrangements such as those described below were common:

My youngest goes four days a week to day care and her grandmother has her on the fifth day. My other daughter goes to school. I take them to school with a friend's children and [the friend] picks up my children three days a week. Our school does not have out-of-school-hours care so we just work it out with friends. On one day I finish early and pick her up. (Male employee)

Use of family carers (typically grandparents) was a common type of informal arrangement, prompted in part by the difficulty of finding sufficient and suitable childcare and by concem about the cost. Networks of tamily and friends to assist with caring responsibilities were described as especially important in the early stages of return to work and also in managing childcare costs: 'a big part of my decision to come back full-time, was the fact that I had my mother for full-time care' (Manager).

Parents also described the need to have access to care structures to meet irregular or unpredictable requirements such as child illness, carer illness (in the case of informal carers), or events such as pupil-free days or teacher strikes. While access to formal organisational provisions such as family leave was important, participants also described needing to create alternative care structures on an 
informal basis to manage these needs. These included bringing children to work, calling on family (especially grand parents) and friends at short notice, or self-care by school-age children.

The ca pacity to vary working time was also raised as a way to manage work and care commitments. Part-time work was an obvious option to reduce working hours, but for full-time workers there were a number of emerging informal opportunities for flexibility in their working arrangements. These were generally ad hoc, varied from workplace to workplace, and had not been codified in any organisational policy.

Flextime weekly hours and working from home were two examples. As discussed in Whittard (2004), the importance of facilitating employee-based flexibility in hours was recognised by line managers, but facilitating this required a complex balancing act. Within the head office, for example, some managers allowed staff to vary their working hours from day to day so as to assist with caring commitments. As one HR Officer explained:

We have a couple of mothers in head office here. Both of them were having trouble on Tuesdays and Thursdays, so they have adjusted their hours to leave early on those days and they make the time up on the other days.

However, it was also revealed that other departments at Head Office were more resistant to these ideas, as one manager described:

[In this department] we just brought in a whole pile of flexibility in working hours. Unfortunately, in the past it was left to individual departments, so some of them stuck to 9 to 5 because it suited them.

How did this flexibility emerge? HR indicated that operational requirements within Head Office departments were one of the mediating factors in the introduction of these practices: 'the few people we have got working flexitime at head office, they are doing tasks that fit in with the department ... it doesn't worry anyone else'.

The introduction of informal arrangements for flextime was also heavily dependent on HR intervention:

Each [case where flextime was introduced] was actually driven from here [HR]. The staff came to us and said 'What can we do?'. I said 'I believe we can do it, let's go and talk to your department manager and see if it can fit in'. And in all those cases it has. There has been a request from the staff member, HR department says, 'Yes, we can do that', and then it has blended in with the timing of the departments. Some departments have different tasks you can't change the timing of. It depends on what task that person has got in 
that department, whether they can fit in with early starts and finishes. (IR Officer)

Part of this HR support involved negotiating with managers and overcoming manager resistance to employee-based flexibility in working hours by emphasising its limited scope and application:

One [manager] was very reluctant initially because he said, 'We have got fourteen employees in the department. What if they all want to do it?' I said, 'Well, if they all want to do it they can't because we have to fit in with the department. They are all not having babies anyway and basically it's all to do with childcare and out-of-work-hours care. The fourteen people wouldn't do that'. Once we had explained how it would work, how it would fit in, he was most supportive and just this week he said it is working very well. (HR Officer)

Working at home was also an option available to some full-time employees. Some employees at head office, in particular those without the face-to-face client responsibilities, said they could use the flexibility of task-based duties to shift the performance of some work tasks to the home. As one Head Office manager argued:

I think we are fairly flexible here. We are lucky in the fact that our work flow is such that we are not always working to deadlines. Every thing can be put off. In my example, with my wife being crook, I might have to leave early but I will take my work home and do it at night. I don't have to be at work to do my work. I can sit at home and do it, which is good.

Finally, this case study also revealed opportunities for implementing flexibility within full-time working hours in the main customer contact areas of the organisation, the branch network. The organisation emphasised that at its discretion it would allow employees to access time-in-lieu for overtime longer than fifteen minutes per day. While not explicitly stated in policy, it was revealed in interviews, that this occurred on an informal basis when there were family reasons and at the discretion of line managers. As a personnel manager indicated, within the branch network some flexibility in working hours was available to employees, because,

... most of our managers are pretty flexible and they help out with that sort of thing ... Okay, you work 9 to 5 , but if someone has to leave at 4.30 or 4 because they have to take the kids to doctors or they have to go to some appointment, they usually will. 
However, difficulties in accessing this provision within the branch network were acknowledged. The HR manager stated 'it would be harder out in the branches because they are open from 9 to $5^{\prime}$.

Informal organisational practices played a significant role in supporting employees with their work-and-family commitments (Lewis and Taylor 1996, Schwartz 1994). The interviews revealed the individual workplace as the main determinant of informal access to support for work-and-family interaction. It was the first point of contact with FinanceCo for employees with family concerns and the primary site of impact for such pressures. As mentioned earlier, this can require some kind of work intensification in the office.

It was evident throughout this case study that work-and-family issues affected a line manager's immediate workplace environment. Of particular relevance were short-notice care problems, for example 'sick calls' (line manager), as well as the general desire for time off for 'non-crucial' care work. Managers indicated this difficulty with statements such as, "There is always things where people need an hour here or there... There is a constant impact of family issues on the normal 9 to 5 working hours' (line manager). Another manager described the demand in this way:

Number one would be being called during work time to say the child is sick, you need to come and get them because the day care place won't keep them if they are ill. So [the parent has] to drop everything and go ... and the rest of the branch has to support the decision and work a bit harder to cover that person ... It seems to always be the mothers though. I often wonder do the husbands never get the phone call? It is always the mothers!

Demand for non-crucial flexibility involved such needs as adjustment to parental requirements due to new school hours/days, appointments, and children's events. As one manager described it, 'I understand the importance of being able to see the school play. If anybody needs their lunch-time at a different time to do that sort of thing ... I think that is important for the family life as well'.

On the matter of informal time-in-lieu, one FIR Officer explained:

There is nothing set down that we have flexitime in our staff agreement. But out in the branches if they have appointments or school interviews with their children, they can make up their time elsewhere. Sometimes even that doesn't really happen because if you see an employee has worked hard for the last couple of months, you are quite happy for them to go home, you know, an hour earlier to attend a school interview.

There were a number of informal mechanisms to accrue time-in-lieu, 'make up' time and time off as a 'reward' in place in different workplaces. These systems 
operated totally informally and were entirely up to the discretion of the line manager. Some managers allowed employees to work through lunch hours or tea breaks so they could have time off later in the day or leave early. Others provided opportunities to start late on one day and compensate for the time lost at a later date, for example, 'pay[ing] back the hours by having a shorter lunch time for a few days or something like that' (line manager). It was also revealed that while some branches and managers ensured employees 'made up' any time taken out of the workplace and recorded all overtime performed to provide time-in-lieu there was a recognition that in a number of branches staff were not always asked to make up the time because of the regularity of extra unpaid hours. As this manager described, "They often say, "I will make up time" and I say, "No that is fine", because they do do more ...' Another line manager described her choice to relieve employees of the need to make up time taken for family commitments, because all the girls that work for me work longer hours than they are paid for so it just becomes a bit of a catch up'. Some managers even left it up to the employees to decide if they needed to make up time: 'More than likely what the people involved do is try to make it up. They don't have to but they feel as if they should so that is up to them' (line manager). Within other workplaces there were systems of reward for sales performances and meeting branch sales targets where'informally they [managers] might give time-off-in-lieu for people who contribute really well with the product selling' (line manager).

Finally, it was identified in manager interviews that granting requests for time flexibility became part of an exchange of loyalty between a manager and employee. A 'give and take' process was described that was very dependent on the manager's perception of gain in return:

It does depend on the branch and the manager. If you are a taker and you are taking all the time, then of course, if you are asking for time off, then ... you are going to be told, "No, you can't". But if you give as well as take, then yes, it is very flexible. (Line manager).

An example of the 'give' required to earn line managers' support in this area was encapsulated by these manager's comments:

If you come in 9 to 5 , have exactly your hour for lunch, have your morning tea break when you are entitled to it and have your exact fifteen minutes and you don't give one iota extra, I have the feeling that you either don't deserve or will not receive any [support] in retum. However if you are the sort of person who gives that extra bit, you will.

Regardless of the willingness of managers, facilitating informal flexibilities or dealing with short-term crucial care needs often required 'reshuffling staff, re- 
juggling lunch hours, changing things', and so on. If there were no replacement staff sent from HR, then the branch had to perform 'one short' for the rest of the day and 'work harder'. This meant other employees in the branch had to do the work of the absent person as well as their own (line manager). Line managers, on the other hand, could also choose to intensify their own work, a situation in which, as one manager described, they themselves would ofter have to 'go out and turn into a cashier to make sure they still have the cashiers on the counter'. The degree to which line managers were able to 'help out' in many ways required a delicate balance of competing interests. The concern for staff and their caring commitments had to be assessed against how much 'harder' the workplace would have to work to provide this flexibility, at the same time as perceptions of equity between staff members were maintained.

\section{Conclusion}

This case study demonstrates the collision between the flexibility of labour use in an organisation and the working-time flexibility of employees. In Australia, the traditional way to reconcile work and care is through patt-time work. In this case study the challenges facing full-time workers in reconciling work and care were illustrated. In the context of a retail banking operation, operational requirements and the need to complete the job on a day-by-day basis meant there were major challenges in fulfilling planned and unplanned care commitments. Full-time employees were dependent on the goodwill and the understanding of line managers and fellow employees in meeting such needs. Informal arrangements were imperative within and outside of the workplace. Within the workplace, the ability to negotiate arrangements with supervisors was essential. However, in this process the unwritten negotiation required employees to accept longer hours for the office's operational requirements. Even where there was a formal entitlement to leave, accessing it was often negotiated through an unwritten contract with line managers. Having an entitlement is not sufficient to meet unexpected care needs (Charlesworth et aI. 2002).

The collision between the individual's family commitments and the employer's interests was evident in a number of areas. This extended to a collision amongemployees themselves, and between managers. The case study investigates the constraints faced by a growing component of the Australian workforce - fulltime employees with care responsibilities. At FinanceCo, this type of employee, generally female, nade up a significant and important share of the workforce, and the ongoing functioning and effectiveness of the organisation was underpinned by many workers managing work-and-family needs. This is in the context of an industry that requires both numeric and functional flexibilify in its labour use. The 
formal and informal operational aspects of its full-time working arrangements created pressure for employees with care commitments. Women working full-time in particular highlighted the challenge of trying to meet both work and family demands. In common with the overall Australian work-and-family regime, there was an absence of formal mechanisms and processes in place to support planned and unplanned work and family conflicts. While care arrangements were important for facilitating attendance at work, work-time flexibility was also essential. In practice, workers were largely dependent on informal support mechanisms within the family and the workplace to manage their work and family interaction. At the workplace such support depended upon the goodwill and support of line managers.

\section{Endnotes}

1. For the purposes of this article, line managers are defined as 'middle and junior level managers that undertake general management work', following Renwick and MacNeil (2002: 413). It also includes supervisory staff or 'first line managers' (Legge 1995: 202).

\section{References}

Bardoel, A (2003) 'The provisions of formal and informal work-family practices: The relative importance of institutional and resource dependent explanations versus managerial explanations' Women in Management Review, 18(1/2), pp. 7-19.

Berg, P, Appelbaum, E, Bailey, T, Kalleberg, A L (2004) 'Contesting Time: International Comparisons Of Employee Control Of Working Time' Industrial E Labor Relations Revicu, 57(3), pp. 331-49.

Bittman, M and Rice, J (2002) 'The Spectre of Overwork: An Analysis of Trends between 1974 and 1997 Using Australian Time-series Diaries', Labour \& Industry, 12(3), pp. 5-26.

Campbell, I and Charlesworth, S (2003) 'Family friendly benefits in Australia: Are they Adequate?' in M Baird and J Burgess (eds) Employee Entitlennents in Australia, Employment Studies Centre Monograph No.3/2003, University of Newcastle, pp.66-82.

Campbell, I and Charlesworth, S (2004) Background Report: Key Work and Family Trends in Australia, Centre for Applied Social Research, RMIT, Melbourne.

Charlesworth, S, Campbell, I, Probert, B, with Allan, J and Morgan, L (2002) Balancing Work and Family Responsibilities: Policy Implementation Options, report prepared for the Victorian Department of Premier and Cabinet and Department of Innovation, Industry and Regional Development, Department of Employment and Workplace Relations, Melbourne. 
Currie, G and Proctor, S (2001) 'Exploring the relationship between HR and middle managers', Human Resource Management Journal, 11(3), pp. 53-69.

Dex, $S$ and Scheibl, $F$ (2001) 'Flexible and family-friendly working arrangements in UK-based SMEs: Business Cases', British Journal of Industrial Relations, 39(3), pp. 411-31.

Eaton, S (2003) 'If you can use them. Flexibility policies, organizational commitment, and perceived performance', Industrial Relations, 42(2), pp. 145-167.

Felstead, A, Jewson, N, Phizacklea, A and Walters, S (2002) 'Opportunities to Work at Home in the Context of Work-Life Balance', Human Resource Management Journal, 12(1), pp. 54-76.

Fletcher, J and Rapoport, R (1996) 'Work and family issues as a catalyst for organizational change' in S Lewis and J Lewis (eds) The Work-Family Challenge: Rethinking Employment, Sage, London, pp. 142-58.

Hein, C (2005) Reconciling Work and Family Responsibilities, ILO, Geneva.

Kitay, J and Callus, R (1998) 'The role and challenge of case study design in Industrial Relations research' in K Whitfield and G Strauss (eds) Researching the World of Work: Strategies and Methods in Studying Industrial Relations, ILR Press, Ithaca, New York, pp. 101-12.

Legge, K (1995) Human Resource Management: Rhetorics and Realities, Macmillan, London.

Lee, I (2001) 'Work/family balance and family responsive working arrangements' in D Kelly (ed), Proceedings of the 15th AIRAANZ Conference, Volume 2, Unrefereed papers, 31 January to 3 February, Wollongong, pp. 72-9.

Lewis, S and Taylor, K (1996) 'Evaluating the Impact of Family Friendly Employers Policies: A Case Study' in S Lewis and J Lewis (eds), The Work-Family Challenge: Rethinking Employment, Sage, London, pp. 1-19.

Morehead, A (2003) 'Managing flexible working time arrangements: Negotiations between mothers and managers in a Canberra hospital', Labour \& Industry, 14(1), pp. 91-106.

Pocock, B (2003) The Work/Life Collision: What Work is Doing to Australians and What to Do About It, Federation Press, Sydney.

Renwick, D and MacNeil, C (2002) 'Line manager involvement in careers', Career Development International, 7(7), pp. 407-14.

Sheridan, A and Conway, L (2001) 'Workplace flexibility: Reconciling the needs of employers and employees', Women in Management Review, 16(1), pp. 5-11.

Schwartz, D (1994) An Examination of the Impact of Family-Friendly Policies on the Glass Ceiling, Families and Work Institute, New York, monograph PDF file accessed from $\langle w w w$.ilr.cornell.edu/library $\rangle, 5$ February 2002.

Thomthwaite, L (2002) Work-family balance: International research on employee preferences, ACIRRT working paper 79; paper presented to the Working Time Today Conference, 16 August 2002. 
Thornthwaite, L (2004) 'Working Time and Work-Family Balance: A Review of Employees' Preferences', Asin Pacific loumal of Human Resources, 42(2), pp. 166-184.

Whittard, J (2004) 'Caught between a rock and a hard place?: Line manager's experiences of managing work and family issues', AIRAANZ Conference Proceedings Vol. 2, unrefereed abstracts and papers. AIRAANZ Conference 2004, 3 to 6 February.

Wise, S and Bond, S (2003) 'Work-life policy: Does it do exactly what it says on the tin?' Women in Management Rerview, 18(1/2), pp. 20-31.

JENNY WHITTARD AND JOHN BURGESS - School of Business and Management, University of Newcastle 